\title{
精细化管理在埃塞 MH 高速公路项目施工成本管控中的应用
}

\section{Application of Fine Management in Construction Cost Control of Essy MH Expressway Project 孙岐}

Qi Sun

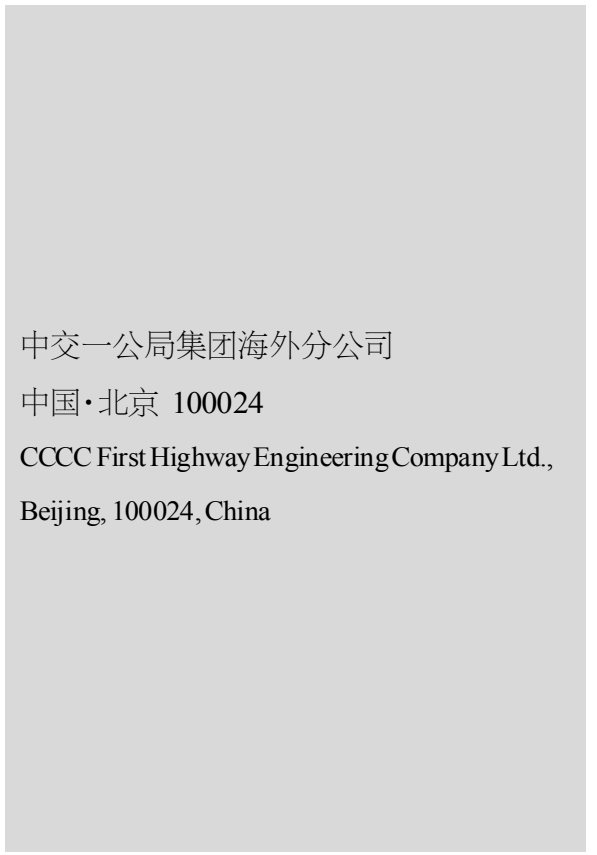

\section{1 引言}

成本控制贯穿于工程项目建设的全寿命周期，对施工项 目进行成本控制就是通过对建筑企业施工成本与预算成本的 比较,达到节省支出、控制成本、实现盈利的目的。因此,如何 提高施工成本管理的方法和水平,对施工企业来说,是一个具 有现实意义的研究课题。

精细化管理是一种理念和文化, 是一种以最大程度减少 管理所占用资源和降低管理成本为主要目标的管理方式。文 章以埃塞 Modjo-Hawassa (简称“MH”) 高速公路项目建设为 例, 研究了国际工程项目精细化施工成本控制的基本方法,以 期为国际同类工程项目提供理论和经验的参考。

\section{2 埃塞 $\mathrm{MH}$ 高速公路项目情况概述}

埃塞 MH 高速公路项目全长 $201.68 \mathrm{~km}$ ，为双向四车道 高速公路,业主方为埃塞俄比亚国家公路局。该项目全线共 划分为四个标段, 中方承建的是第四合同段,合同路线长度 为 $51.68 \mathrm{~km}$, 合同类型为设计施工总承包项目, 合同金额为 2.01 亿美元,合同工期为 42 个月 (自 2018 年 3 月 7 日开工起 算), 缺陷责任期为 1 年,质保期为 3 年。
该项目作为 “一带一路” 倡议的重要建设项目, 在该项目 中积累的工程管理经验对于中国今后在类似地区开展工程 建设具有重要的借鉴价值。因此,结合该项目探索精细化管 理在海外工程项目施工成本控制中的应用, 具有重要的理论 价值。

3 埃塞 $\mathrm{MH}$ 高速公路项目施工成本管控 中存在的问题

\section{1 依据施工合同进行成本管控的意识淡薄}

在实际项目施工过程中，人们总是简单地将成本控制归 结为财务部门在项目经理的领导下开展的与成本开支及核算 有关的财务操作, 而忽略依据施工合同带动全员参与施工成 本控制, 以达到事半功倍的效果 ${ }^{[1]}$ 。工程施工合同是项目参建 各方就建设目标更好实现而达成的一致性认识，只有严格依 照合同落实施工安排, 才能避免过多的技术变更最后影响工 期和成本，才能在工程一开始编制成本计划时就调动所有部 门通力合作的积极性。

\section{2 依据成本计划进行精细化管控的措施不到位}

施工成本计划是进行施工成本管理的重要依据, 在实际 施工过程中要定期对照成本计划检查成本管理阶段性的效 
果。成本计划中规定的中标合同价需要所有参建部门努力配 合去管控 ${ }^{[2]}$; 人、材、机等的价格容易受到地理位置及经济形 势的影响而发生变动, 需要动态调整、合理平衡, 分阶段实现 与成本计划的吻合; 摒弃传统的粗放式管理方式, 科学、合理 地对成本计划进行细化，建立权责利制度保证成本计划得到 良好的贯彻落实。

\section{3 海外项目施工成本受到更多因素的综合作用}

在海外开展项目施工, 施工成本受到的不可控因素更多, 实现施工利润最大化难度更高。海外项目中, 建筑材料受到当 地经济形势、政府政策等的影响,还要考虑汇率差异; 建筑机 械的使用可能需要协调更多的部门, 无形中增加了管理成本; 有更多的协作单位参与进来，每个协作单位都有自己的特点 和工作习惯差异, 这会给施工的管理和经营带来更多的不可 控风险。因此, 对海外工程项目来说, 更要提高管理水平, 通过 精细化管理最大限度地控制施工成本。

\section{4 埃塞 $\mathrm{MH}$ 高速公路项目施工成本管控 措施}

结合埃塞 MH 高速公路项目特点及其施工成本管控的特 殊性, 通过采用精细化施工成本管控措施实现成本管控效益 的最大化,需要做好以下几方面的工作。

\section{1 参建各方进一步强化施工成本精细化管理} 理念

企业实施精细化成本管理, 必然要求一切和成本管理有 关联的人员都要参与其中, 自觉养成降低成本、控制支出的习 惯, 只有全员、各部门的各项成本得到控制, 施工总成本才有 可能得到控制。同时, 建设方还要结合项目进展和实际情况, 制定各项成本节约奖励办法, 将成本节约情况与相关人员的 绩效挂钩,调动员工参与施工成本管理、节约成本实现增收的 积极性。

\section{2 做好施工过程中相关成本的精细化管控}

与施工成本关系最密切的因素是材料及运输价格。海外 项目施工企业一方面要力争与当地资信情况良好的原材料供 应商通过招投标方式建立长期稳固的合作关系，制定协议价 和保护价; 另一方面, 制定限额领料制度。施工企业要对施工 材料进行限量调拨, 根据现场实际需要和定额损耗率调拨材 料, 控制材料损耗。同时, 企业还要对材料的价差量差进行管 理, 通过对于材料价差量差的比较, 来核准新的损耗率。

另外, 施工机械价格也会影响施工成本。机械使用费应当 严格按照预算指标来进行分配, 统筹考虑机械自购与租赁费 用, 关注施工项目与所使用机械设备的匹配度, 进一步降低机
械使用费用在施工成本费用中所占的比重。同时, 对于施工机 械进行限时使用并单机核算，对自营项目进行单独的核算管 理, 责任到人。

\section{3 提高对协作单位的精细化管理水平, 以降低 施工成本}

在项目施工的同时, 要进一步介入协作单位的内部管理 中, 及时指出协作单位中对施工安排不合理、质量安全重视不 重视等问题, 并责令其限期整改。同时,对协作单位要定期性 地进行盈亏核算, 及早发现协作单位在经营方面的风险, 帮助 协作单位实现经营风险可控的目标，这也是规避施工后期经 营风险的重要准则。

建设项目组织方要把所有协作单位作为一个整体来统筹 考虑制定的各项政策、措施，只有所有协作单位的施工成本费 用下降，这些协作单位才会有更大的积极性参与到项目整体 的施工成本管控过程中,才能实现合作共赢。

\section{4 强化以经济活动分析为抓手的成本管控工作}

经济活动分析可以清晰地显示项目的经营及利润情况, 以经济活动分析为抓手,建立项目成本管控体系,提高项目管 理人员的成本意识及索赔意识。这样可以及时发现经营管理 不善的协作队伍,避免日后与协作队伍出现纠纷。通过经济活 动分析可以建立大数据库，为公司投标与成本管控体系的建 立提供有力支撑。

\section{5 结论}

通过实施精细化管理措施，埃塞 MH 高速公路项目施工 成本控制在项目预算之内, 取得了各方都较为满意的效果。在 施工成本精细化管理过程中, 积累的经验经过事实证明是行 之有效的。

在实施精细化管理的过程中, 施工企业还应该建立反馈 机制，根据前期制定的成本控制措施在实施过程中出现的不 完美的地方, 及时进行修订, 实现动态管控。这些需要在今后 的研究中进行进一步的关注和分析。

总之，施工成本精细化管理对于实现项目成本管控和创 利增收具有很大的促进作用, 项目管理层和参与人员都要高 度重视。只有每一位员工都参与到精细化管理过程中来, 才能 使项目预算得到落实, 才能为企业创造良好的经济价值。

\section{参考文献}

[1]陈荣新.工程成本控制中精细化管理研究 [J].现代物业 (中旬 刊),2019(4): 159 .

[2]贾汝涛.浅谈精细化管理—工程成本控制[J].科技信息,2011 (11):668 